\title{
Milestones in the Evolution of
}

\section{Hepatic Surgery}

\author{
Henri Bismuth, M .D., F .A.C.S. (H on)1*, Rony E shkenazy, M .D.2, and Arie Arish, \\ M.D. ${ }^{2}$
}

${ }^{2} \mathrm{H}$ epatobiliary Institute, $\mathrm{P}$ aul Brousse $\mathrm{H}$ ospital, $\mathrm{Paris}$, $\mathrm{F}$ rance, and ${ }^{2} \mathrm{H}$ epato-Biliary Surgery Service, $\mathrm{D}$ epartment of $\mathrm{G}$ eneral Surgery, R ambam $\mathrm{H}$ ealth Care Campus, $\mathrm{H}$ aifa, I srael

\begin{abstract}
This paper describes the rapid evolution of modern liver surgery, starting in the middle of the twentieth century. Claude Couinaud studied and described the segmental anatomy of the liver, Thomas Starzl performed the first liver transplantations, and Henri Bismuth introduced the concept of anatomical resections. Hepatic surgery has developed significantly since those early days. To date, innovative techniques are applied, using cutting-edge technologies: Intraoperative ultrasound, techniques of vascular exclusion of the liver, new devices for performing homeostasis and dissection, laparoscopy for resections, and new drugs that allow the resection of previously unresectable tumors. The next stage in liver surgery will probably be the implementation of a multidisciplinary holistic approach to the liver-diseased patient that will ensure the best and most efficient treatments in the future.
\end{abstract}

KEY WORDS: Surgery, liver, transplantation, transection

The adult liver, the largest organ in the body, accounts for $2 \%-3 \%$ of overall body weight. Richly vascularized, the liver has an inflow carried through the portal vein and the hepatic artery and an outflow draining through the main and accessory hepatic veins. The main portal vein drains the splanchnic territory and carries $70 \%-80 \%$ of the overall hepatic inflow. It divides into two branches, the right and left portal veins, which are then subdivided into sectorial and segmental branches. Blood pressure in the main portal vein is usually low, with a portocaval gradient (i.e. portal vein pressure minus central venous pressure) of less than $5 \mathrm{mmHg}$. In chronic liver disease, especially cirrhosis, the portocaval gradient may increase to the point of portal hypertension.

In the seventeenth and eighteenth centuries,

\footnotetext{
Abbreviations: IOC, intraoperative cholangiography; IOUS, intraoperative ultrasound; PVE, portal vein embolization. Citation: Bismuth H, Eshkenazy R, Arish A. Milestones in the evolution of hepatic surgery. RMMJ 2011;2(1):e0021. doi:10.5041/RMMJ .10021

Copyright: @ 2011 Bismuth et al. This is an open-access article. All its content, except where otherwise noted, is distributed under the terms of the Creative Commons Attribution License (http://creativecommons.org/licenses/by/3.0), which permits unrestricted use, distribution, and reproduction in any medium, provided the original work is properly cited.

Conflict of interest: No potential conflict of interest relevant to this article was reported.

* To whom correspondence should be addressed. E-mail: henri.bismuth@pbr.aphp.fr
} 
liver resections were carried out on trauma victims with a range of injuries occurring as a result of military combat. The first liver resections in a non-emergency setting resulted in uncontrolled bleeding and death.

\section{HISTORY OF MODERN LIVER SURGERY}

The German surgeon Carl J ohann August Langenbuch performed the first successful hepatic resection in 1888 (he was the first to perform cholecystectomy in 1882). ${ }^{1}$ He resected a part of the left lobe of the liver after ligating the vascular pedicles. The pathologic examination of the specimen revealed normal liver.

The first steps leading to modern liver surgery began in the late 1950s. Scattered publications from the United States describing a limited series of liver resections that had met with some success were published. The technique of liver resection at that time was ill defined.2,3

Concomitantly, in 1952 in France Lortat J acob published a manuscript on his experiences performing anatomical liver resections: right hepatectomy after vascular control of the right liver. ${ }^{4}$ In 1956, Claude Couinaud, ${ }^{5,6}$ after studying casts of the liver, published his book, The liver - anatomicalstudies and surgical studies. He showed that, according to the distribution of the portal blood, the liver contains four parts that are subdivided by the hepatic veins into eight segments. He coined the segment numbers as follows: one for the central segment and two through eight for the seven other segments in a clock-wise fashion. This segmental division of the liver is the basis of modern functional and surgical liver anatomy.

Despite the anatomical discoveries of the 1950s, their application in surgical practice was limited. No clinical methods existed that could detect the existence of small liver tumors that might have required segmental resections. Physicians made their diagnoses based on physical symptoms (pain or a palpable tumor), at which point it was usually already too late for surgery. Only large liver resections could be performed.

The introduction of ultrasound in the early $1980 s^{7,8}$ into common clinical practice allowed the clinician to diagnose asymptomatic small liver tumors of 2 and $3 \mathrm{~cm}$ and paved the way to rapid development of liver surgery. In fact, modern liver surgery began when functional liver anatomy discovered 30 years earlier was applied, enabling

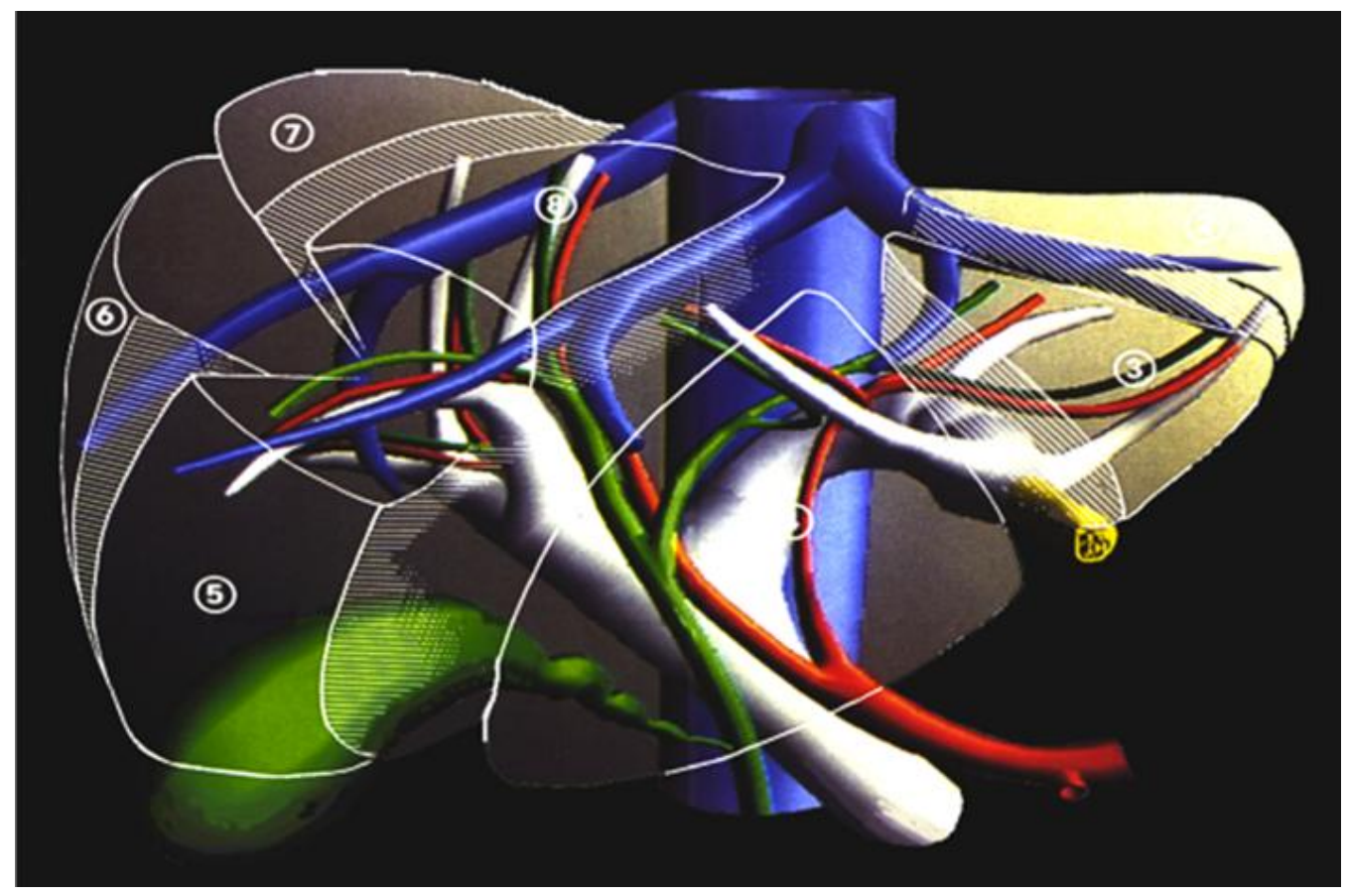

Figure 1. The transparent liver showing the main arteries (in red), portal vein (in white), hepatic veins (in blue), and main parts of the biliary system (in green). Liver segments are numbered, and the round ligament is designated in yellow. 
segmental liver surgery.

The paper with the somewhat provocative title of "Surgical anatomy and anatomical surgery of the liver"9 published in 1982 was a turning-point in the practice of liver surgery. Navigating surgery on the basis of anatomy eliminated the use of "atypical" or "non-anatomical" resections of the liver which had resulted in bleeding, increased morbidity, and mortality sometimes as a result of liver necrosis. Liver resections based on anatomy gained popularity and evolved into bloodless surgery that removed independent segments or groups of two or more segments.

In 1984, intraoperative ultrasound (IOUS) was introduced into practice. ${ }^{10-14}$ The technique allowed the surgeon to understand liver vasculature and biliary duct anatomy and rendered the liver transparent (Figure 1). In fact, the introduction of IOUS into liver surgery had the same impact as the inclusion of intraoperative cholangiography (IOC) fifty years earlier in biliary surgery. ${ }^{15}$ By finding the liver's lines of division with IOUS and looking for a tumor, the surgeon could establish the relations among the portal elements, the hepatic veins, the hepatic parenchyma, and the tumor, and then decide what kind of anatomical resection needed to be carried out - "Hepatectomie à la carte" for each individual patient.

Control of bleeding during liver resection is a major challenge for the surgeon. It is particularly difficult in cirrhotic liver due to the fibrotic nature of the liver tissue. The indication, as well as the type of clamping, depends mainly on the size and location of the lesions to be resected, the quality of the liver parenchyma, the surgeon's preferences, and unexpected operative events. In 1958 Lin introduced the finger fracture technique, which involves crushing of liver parenchyma by the surge on's fingers under inflow occlusion so as to isolate vessels and bile ducts for ligation. ${ }^{16}$ This technique was subsequently improved through the use of surgical instruments such as a small Kelly clamp for blunt dissection (clamp crushing or "Kellyclasia").9,17,18

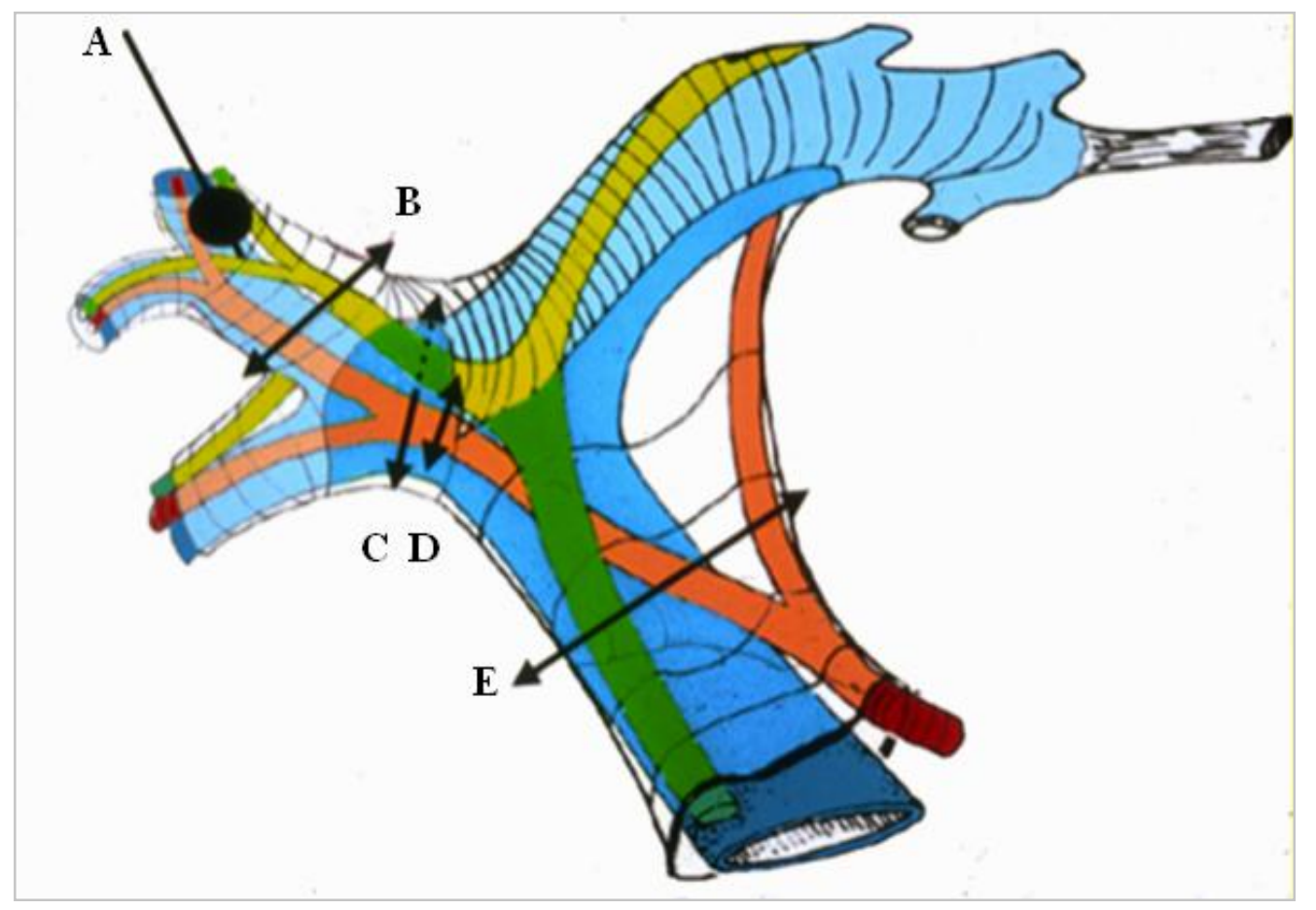

Figure 2. Glissonian pedicle elements: portal vein (in blue), hepatic artery (in red), and the bile ducts (in green). Hepatic inflow occlusion: A) Selective occlusion of segmental portal vein by a balloon introduced under ultrasonographic guidance. The arrows show the different sites of Glissonian clamping. B) Suprahilar clamping of one sector of the right liver; C and D) hilar selective clamping to the right liver; E) total pedicular clamping (Pringle maneuver). 


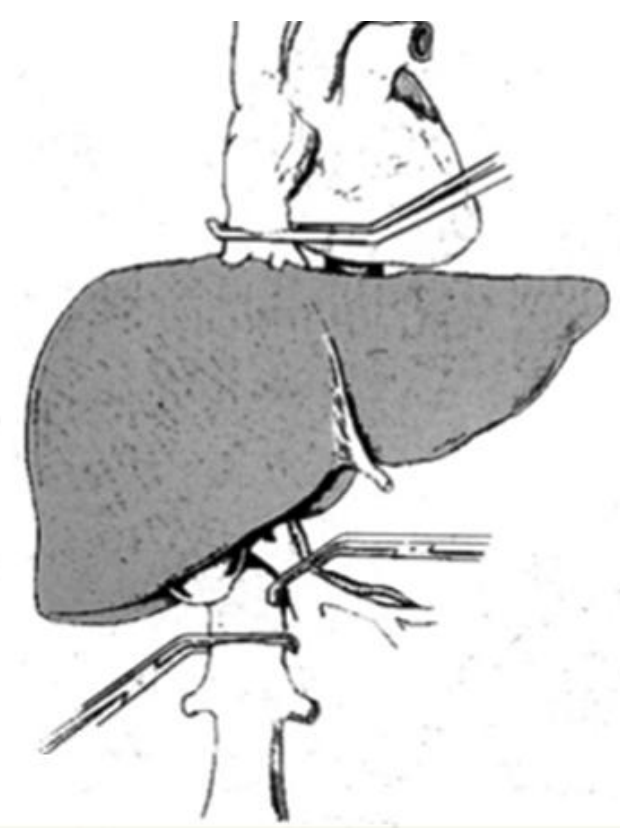

Figure 3. Total vascular exclusion of the liver by clamping the infrahepatic and suprahepatic inferior vena cava and the hepatoduodenal ligament.

In many centers, ultrasonic dissection using the Cavitron Ultrasonic Surgical Aspirator (CUSA; Tyco Healthcare, Mansfield, MA, USA) has become the standard technique for liver parenchyma dissection. With this technology, the liver tissue is fragmented with ultrasonic energy and aspirated, thus exposing small vascular and ductal structures that can be ligated or clipped with titanium hemoclips. ${ }^{19}$ The water jet dissector employs a pressurized jet of water instead of ultrasonic energy, in order to fragment the liver parenchyma tissue and expose the vascular and ductal structures. ${ }^{20}$ However, this technique has not become as popular as ultrasonic dissection.

To reduce blood loss during liver resection, intermittent inflow occlusion by clamping of the portal triad (Pringle maneuver) is frequently used. ${ }^{21,22}$ However, there is a limit to how long the Pringle maneuver can be applied. Prolonged inflow occlusion (over 120 minutes) may have deleterious effects on liver functions. ${ }^{23}$ Hepatic inflow occlusion can be directed to one side or to a segment by clamping the Glissonian pedicle at the hilum or inside the liver parenchyma (Figure 2). $9,24-29$

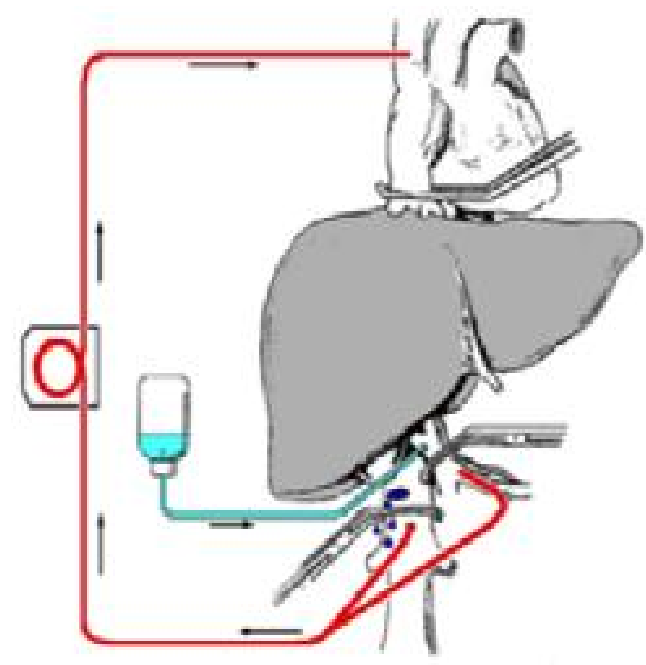

Figure 4. Total vascular exclusion of the liver with hypothermia as described by Fortner et al. ${ }^{40}$ The liver is excluded (as in Figure 3). Veno-venous bypass of the liver is performed (red lines), and hypothermic solution is infused into the portal vein (in blue).

The majority of liver resections can be done with no clamping at all. ${ }^{30,31}$ In some patients total hepatic vascular isolation is needed. This isolation can be partial (meaning occlusion of the inflow and only one hepatic vein 32,33 ) or total (meaning occlusion of the inflow). Outflow occlusion is obtained by occluding the vena cava above and below the hepatic veins ${ }^{34-37}$ (Figure 3). In cases of a small tumor adherent to a hepatic vein, isolation of the corresponding liver by clamping the inflow and the hepatic vein can facilitate and render surgery safe if the lesion is resected with the adherent vein. When a large tumor is found to have entered the vena cava, this technique enables bloodless resection of the involved vena cava and safe reconstruction of its continuity.38,39 Total vascular exclusion (TVE) of the liver can be applied safely for as long as 60 minutes. This can be extended to 8 hours by using hypothermia (Figure 4), as is done in liver transplantation. The liver resection can be done in situin vivo as first described by Fortner et al. ${ }^{40-42} \mathrm{ex}$ situ in vivo as described by Hannoun et al., ${ }^{42-45}$ or ex situ ex vivo as described by Pichlmayr et al. 46 (Figure 5, next page). This innovative approach to liver resection has a high rate of complication and even mortality.

Another concept in liver surgery that guides 

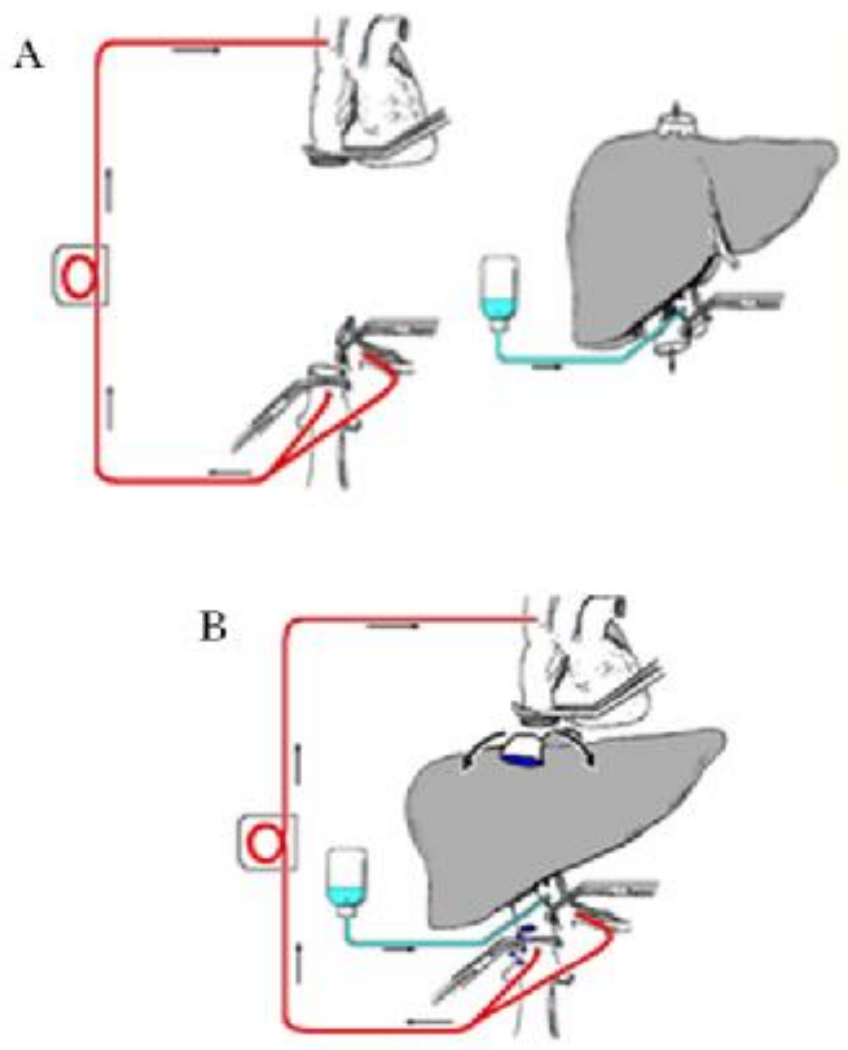

Figure 5. Total vascular exclusion for complex liver resections. A) The ex-situex-vivo technique described by Pichlmayr et al. ${ }^{46}$ B) The ex-situin-vivo technique described by Hannoun et al. ${ }^{43}$

surgeons toward safe surgery is that "the liver is parenchyma tissue with blood vessels inside". The rationale behind this concept is to dissect this parenchyma tissue while ensuring hemostasis. The concept was popularized following the development of new devices that enabled such dissection, e.g. the harmonic scalpel, ${ }^{47-49}$ LigaSure, ${ }^{50-52}$ tissue link, 53 radiofrequency, 54,55 and the "Habib sealer" ${ }^{56,57}$ These devices allow the parenchyma to be cut without having to clamp the pedicle. Nevertheless, the clamp crushing technique is still widely used. ${ }^{58-61}$

The main indication for liver resection today is liver metastasis resulting from advanced cancers of the colon and rectum. Apart from liver surgery for trauma or hepatocellular carcinoma in cirrhotic patients where the mortality is high, ${ }^{62}$ the overall operative mortality in liver resections is be tween $0 \%$ and $2 \% .63,64$ Trained liver surgery teams can achieve less than $1 \%$ mortality. This is a great advance in comparison to the mortality in liver surgery in early reports, which reached a mortality rate as high as $20 \% .65$

\section{LIVER SURGERY - A NEW SPECIALTY}

In medicine and surgery, the use of special technologies and knowledge has facilitated the development of subspecialties. Cardiac surgery, for example, emerged as a specialty of surgery because of the use of special machines and instruments. This was not the case for liver surgery.

When it began, liver surgery used nothing but the instruments of general surgery. Today, with 
the exploitation of special technology and instrumentation such as operative ultrasound, ultrasonic dissectors, argon coagulators, cryotherapy, radiofrequency, and extracorporeal circulation, liver surgery has become a subspecialty of general surgery, or more precisely, a hyper-specialty.

One step on the way to liver surgery becoming a specialty was the advent of liver transplantation. When liver surgeons began performing transplantation, liver resection was a step in the procedure. Surgery on the graft itself or on the recipient, which may have meant heterotopic liver transplantation and reducing the size of the graft,66,67 operating on the living donor, ${ }^{68}$ performing a domino transplantation, ${ }^{69,70}$ or a split liver procedure, ${ }^{71-74}$ were all done by liver surgeons doing liver transplantation.

Liver surgery is now a specialty, as one of the three branches of gastro-intestinal (GI) surgery. These are upper GI, colorectal, and hepato-biliopancreatic surgery. Moreover, it is not a narrow field of surgery. Today's liver surgeons need to master a variety of techniques and tactics: open liver surgery, laparoscopic surgery, endoscopic surgery, and percutaneous surgeries (minimal access surgery).

The two branches, liver surgery and liver transplantation, overlap:

- Techniques of liver transplantation in liver surgery: External bypass in extensive resections, cooling (topical, hypothermia, ex-situ resections).

- Techniques of liver surgery in liver transplantation: Reduced size graft, split liver, living donor.

Today's liver surgeon needs to be familiar with anatomy, echography, vascular surgery, microsurgery, immunology, hepatology, and oncology.

\section{THE PRESENT}

Improving the technique of liver resection and increasing the number of patients eligible for liver resection are the main objectives because the only way to cure a patient, in cases of liver tumors, is to offer him or her the chance of a liver resection.

There are two main ways to render a patient eligible for liver resection: by changing the tumor size through chemotherapy or changing the remaining liver size by performing portal vein embolization. ${ }^{75-80}$

In cases of multiple, bilateral, unresectable colorectal liver metastases, the strategy must be multimodal, starting with neoadjuvant chemotherapy. In patients with a normal liver, portal vein embolization (PVE) is indicated when the future liver remnant volume is predicted to be $<30 \%$. $81-95$ PVE may also be useful in patients who have evidence of chemotherapy-related liver injury. If there is a positive response to chemotherapy, then surgery should follow. Limited resection of the colorectal liver metastases in one lobe can be performed as the first stage combined with radio frequency ablation of other lesions and PVE of the contralateral portal vein. Alternatively, ligation and alcoholization of the portal vein can be performed intraoperatively. PVE, ligation, and/or alcoholization produce, on the one hand, essential atrophy of the implicated lobe and, on the other hand, significant hypertrophy of the contralateral lobe. This strategy enhances the volume of the future liver remnant. Studies have shown an approximately $10 \%-25 \%$ increase in the size of the liver remnant after PVE. ${ }^{81-95}$ The hypertrophy is complete by the third week. In a second stage, a major resection of the contralateral liver can be carried out safely. ${ }^{96-98}$ Usually, patients undergoing these procedures receive postoperative chemotherapy. With this approach, currently there are no limits to the resection other than those imposed by the volume and function of the liver remnant.

Is laparoscopic liver surgery an abdominal approach or a technical improvement? It is too early to compare laparoscopic and open surgery since there are much fewer laparoscopic liver resections reported 99,100 than open liver resections. Many thousands of open liver resections are performed every year. Laparoscopic liver surgery is feasible and safe for certain indications, e.g. left lateral segmentectomy for benign or malignant disease.101-106 Harvesting of the left lateral segment for living related transplantation is done by laparoscopy by some expert surgeons (experts in liver surgery, liver transplantation, and laparoscopy)with excellent results. ${ }^{107}$

There are some reports on robotic liver resections, though these are still preliminary descriptions. ${ }^{108}$ 


\section{THE FUTURE}

The future of liver surgery and new developments in the field are moving in a multidisciplinary direction. Today, oncologists, hepatologists, surgeons, endoscopists, radiologists, pathologists, and researchers are all members of the team treating patients. Their joint efforts are intended to give patients the best and most efficient treatment. In the coming years, the positive results of this cooperation should lead to new and successful treatment procedures.

\section{REFERENCES}

1. Langenbuch C. Ein Fall von Resecktion eines linksseitigen Schnurlappens der Leber. Berl Klin Wochenschr 1888;25:37. German

2. Quattlebaum JK, Quattlebaum JK Jr. Technic of hepatic lobectomy. Ann Surg 1959;149:648-51. doi:10.1097/00000658-195905000-00005

3. Fineberg C, Goldburgh WP, Templeton JY 3rd. Right hepatic lobectomy for primary carcinoma of the liver. Ann Surg 1956;144:881-92. doi:10.1097 /00000658-195611000-00013

4. Lortat-J acob J L, Robert HG. Well defined technic for right hepatectomy. Presse Med 1952;60:54951. French

5. Couinaud C. Lobes et segments hépatiques. Presse Med 1954;62:709. French

6. Couinaud C. Le foie. Paris: Masson; 1957. French

7. Stellamor K. [About the advantages of the sonographic diagnostic in the field of the radiologist (author's transl)]. Rontgenblatter 1976;29:544- 52. German

8. Gosink BB. Evaluation of hepatic neoplasms. AJ R AMJ Roentgenol 1980;134:621.

9. Bismuth H. Surgical anatomy and anatomical surgery of the liver. World J Surg 1982;6:3-9. doi:10.1007/BF01656368

10. Makuuchi M, Hasegawa H, Yamazaki S. Intraoperative ultrasonic examination for hepatectomy. Ultrasound Med Biol 1983;Suppl 2:493- 7.

11. Makuuchi M, Hasegawa H, Yamazaki S. Development on segmentectomy and subsegmentectomy of the liver due to introduction of ultrasonography. Nippon Geka Gakkai Zasshi 1983;84:913- 7. J apa- nese

12. Bismuth H, Castaing D. Peroperative echography in hepatobiliary surgery. Ann Gastroenterol Hepatol (Paris) 1984;20:221-3. French

13. Bismuth H, Castaing D, Kunstlinger F. Peroperative echography in hepatobiliary surgery. Presse Med 1984;13:1819-22. French

14. Bismuth $H$, Houssin D, Castaing D. Major and minor segmentectomies "réglées" in liver surgery. World J Surg 1982;6:10-24. doi:10.1007/BF0165 $\underline{6369}$

15. Neuhaus W. [Intraoperative manometry and roentgenography of biliary system and its significance for surgery of the bile ducts]. Langenbecks Arch Klin Chir Ver Dtsch Z Chir 1953;275:395403. doi:10.1007/BF01438628

16. Lin TY, Tsu K, Mien C, Chen C. Study on lobectomy of the liver. J Formosa Med Assoc 1958;57: $742-9$.

17. Lin TY. A simplified technique for hepatic resection: the crush method. Ann Surg 1974;180:28590. doi:10.1097/00000658-197409000-00005

18. Lin TY. Results in 107 hepatic lobectomies with a preliminary report on the use of a clamp to reduce blood loss. Ann Surg 1973;177:413-21. doi:10. 1097/00000658-197304000-00006

19. Pamecha V, Gurusamy KS, Sharma D, Davidson BR. Techniques for liver parenchymal transection: a meta-analysis of randomized controlled trials. HPB (Oxford) 2009;11:275- 81.

20. Rau HG, Wichmann MW, Schinkel S, et al. [Surgical techniques in hepatic resections: Ultrasonic aspirator versus J et-Cutter. A prospective randomized clinical trial]. Zentralbl Chir 2001;126:58690. German doi:10.1055/s-2001-16573

21. Pringle JHV. Notes on the arrest of hepatic he morrhage due to trauma. Ann Surg 1908;48:5419. doi:10.1097/00000658190810000-00005

22. Man K, Fan ST, Ng IO, Lo CM, Liu CL, Wong J. Prospective evaluation of Pringle maneuver in hepatectomy for liver tumors by a randomized study. Ann Surg 1997;226:704-13. doi:10.1097/00000 658-199712000-00007

23. Man K, Fan ST, Ng IO, et al. Tolerance of the liver to intermittent pringle maneuver in hepatectomy for liver tumors. Arch Surg 1999;134:533-9. doi: 10.1001/archsurg.134.5.533

24. Lazorthes F, Chiotasso P, Chevreau P, Materre J P, 
Roques J. Hepatectomy with initial suprahilar control of intrahepatic portal pedicles. Surgery 1993;113:103- 8 .

25. Launois B, Jamieson GG. The posterior intrahepatic approach for hepatectomy or removal of segments of the liver. Surg Gynecol Obstet 1992; 174:155- 8 .

26. Figueras J, Lopez-Ben S, Llado L, et al. Hilar dissection versus the "glissonean" approach and stapling of the pedicle for major hepatectomies: a prospective, randomized trial. Ann Surg 2003; 238:111-9. doi:10.1097/000006582003070 00$\underline{00015}$

27. Shimamura Y, Gunven P, Takenaka Y, et al. Selective portal branch occlusion by balloon catheter during liver resection. Surgery 1986;100:938-41.

28. Castaing D, Garden OJ, Bismuth H. Segmental liver resection using ultrasound-guided selective portal venous occlusion. Ann Surg 1989;210:20-3. doi:10.1097/00000658-198907000-00003

29. Bismuth H, Houssin D, Castaing D. Major and minor segmentectomies "reglees" in liver surgery. World J Surg 1982;6:10-24. doi:10.1007/BF0165 $\underline{6369}$

30. Capussotti L, Muratore A, Ferroro A, Massucco P, Ribero D, Polastri R. Randomized clinical trial of liver resection with and without hepatic pedicle clamping. Br J Surg 2006;93:685-9. doi:10.1002/ bjs.5301

31. Nuzzo G, Giuliante F, Giovannini I, Vellone M, De Cosmo G, Capelli G. Liver resections with or without pedicle clamping. Am J Surg 2001;181:23846. doi:10.1016/ S0002-9610(01)00555-4

32. Smyrniotis VE, Kostopanagiotou GG, Contis J C, et al. Selective hepatic vascular exclusion versus Pringle maneuver in major liver resections: prospective study. World J Surg 2003;27:765-9. doi: 10.1007/s00268-003-6978-8

33. Cherqui D, Malassagne B, Colau PI, Brunetti F, Rotman N, Fagniez PL. Hepatic vascular exclusion with preservation of the caval flow for liver resections. Ann Surg 1999;230:24-30. doi:10.1097/ 00000658-199907000-00004

34. Huguet C, Gallot D, Offenstadt G, Coloigner M. [Total vascular exclusion of the liver in extensive hepatic exeresis. Value and limits]. Nouv Presse Med 1976;5:1189-92. French

35. Bismuth H, Castaing D, Garden OJ . Major hepatic resection under total vascular exclusion. Ann Surg
1989;210:13- 19. doi:10.1097/00000658-1989070 $\underline{00-00002}$

36. Offenstadt G, Huguet C, Gallot D, Bloch P. Hemodynamic monitoring during complete vascular exclusion for extensive hepatectomy. Surg Gynecol Obstet 1978;146:709- 13.

37. Huguet C, Nordlinger B, Galopin JJ , Bloch P, Gallot D. Normothermic hepatic vascular exclusion for extensive hepatectomy. Surg Gynecol Obstet 1978;147:689- 93.

38. Maeba T, Okano K, Mori S, et al. Retrohepatic vena cava replacement of hepatic malignancies without using total hepatic vascular exclusion or extracorporeal bypass. Hepatogastroenterology 2001; 48:1455- 60 .

39. Ohwada S, Kawashima Y, Ogawa T, et al. Extended hepatectomy with ePTFE graft vena caval replacement and hepatic vein reconstruction: a case report. Hepatogastroenterology 1999;46:1151- 5.

40. Fortner J G, Shiu MH, Kinne DW, et al. Major hepatic resection using vascular isolation and hypothermic perfusion. Ann Surg 1974;180:644- 652. doi:10.1097/00000658-197410000-00030

41. Azoulay D, Eshkenazy R, Andreani P, et al. In situ hypothermic perfusion of the liver versus standard total vascular exclusion for complex liver resection. Ann Surg 2005;241:277-85. doi:10.1097/ $\underline{01 . s l a .0000152017 .62778 .2 f}$

42. Delrivière L, Hannoun L. In situ and ex situ procedures for complex major liver resections requiring prolonged hepatic vascular exclusion in normal and diseased livers. J Am Coll Surg 1995;181:2726.

43. Hannoun L, Balladur P, Delva E, et al. "Ex situ-in vivo" surgery of the liver: a new technique in liver surgery. Principles and preliminary results. Gastroenterol Clin Biol 1991;15:758-61. French

44. Hannoun L, Borie D, Balladur P, et al. [Ex situ-in vivo hepatic resection. Technique and initial results]. Chirurgie 1992;118:292- 6; discussion 2967. French.

45. Hannoun L, Panis $\mathrm{Y}$, Balladur $\mathrm{P}$, et al. Ex-situ invivo liver surgery. Lancet 1991;337:1616- 7. doi:10 .1016/0140-6736(91)93321-Y

46. Pichlmayr R, Grosse H, Hauss J, et al. Technique and preliminary results of extracorporeal liver surgery (bench procedure) and of surgery of the in situ perfused liver. Br J Surg 1990;77:21-6. doi:10. 1002/bjs. 1800770107 
47. Gertsch P, Pelloni A, Guerra A, Krpo A. Initial experience with the harmonic scalpel in liver surgery. Hepatogastroenterology 2000;47:763-6.

48. Schmidbauer S, Hallfeldt KK, Sitzmann G, Kantelhardt T, Trupka A. Experience with ultrasound scissors and blades (UltraCision) in open and laparoscopic liver resection. Ann Surg 2002;235:2730. doi:10.1097/00000658-200201000-00004

49. Aldrighetti L, Pulitanò C, Arru M, Catena M, Finazzi R, Ferla G. "Technological" approach versus clamp crushing technique for hepatic parenchymal transection: a comparative study. J Gastrointest Surg 2006;10:974-9. doi:10.1016/j.gassur.2006. $\underline{02.002}$

50. Saiura A, Yamamoto J, Koga R, Seki M, Yamaguchi T. Liver transection using the LigaSure sealing system. HPB (Oxford) 2008; 10:239- 43.

51. Ikeda M, Hasegawa K, Sano K, et al. The vessel sealing system (LigaSure) in hepatic resection: a randomized controlled Trial. Ann Surg 2009;250: 199- 203. doi:10.1097/ SLA.0b013e3181a334f9

52. Nanashima A, Tobinaga S, Abo T, Nonaka T, Sawai $\mathrm{T}$, Nagayasu T. Usefulness of the combination procedure of crash clamping and vessel sealing for hepatic resection. J Surg Oncol 2010;102:179- 83. doi: $10.1002 /$ jso. 21575

53. Poon RT, Fan ST, Wong J . Liver resection using a saline-linked radiofrequency dissecting sealer for transection of the liver. J Am Coll Surg 2005;200: 308-13. doi:10.1016/j.jamcollsurg.2004.10.008

54. Stella M, Percivale A, Pasqualini M, et al. Radiofrequency-assisted liver resection. J Gastrointest Surg 2003;7:797-801. doi:10.1016/S1091-255X (03)00137-9

55. Poon RT, Ng KK, Lam CM, et al. Learning curve for radiofrequency ablation of liver tumors: prospective analysis of initial 100 patients in a tertiary institution. Ann Surg 2004;239:441-9. doi:10. 1097/01.sla.0000118565.21298.0a

56. Weber J C, Navarra G, J iao LR, Nicholls J P, J ensen SL, Habib NA. New technique for liver resection using heat coagulative necrosis. Ann Surg 2002; 236:560-3. doi:10.1097/00000658200211000$\underline{00004}$

57. Ferko A, Lesko M, Subrt Z, et al. A modified radiofrequency-assisted approach to right hemihepatectomy. Eur J Surg Oncol 2006;32:1209-11. doi: 10.1016/j.ejso.2006.07.013

58. Jarnagin WR, Gonen $\mathrm{M}$, Fong $\mathrm{Y}$, et al. Improve- ment in perioperative outcome after hepatic resection: analysis of 1,803 consecutive cases over the past decade. Ann Surg 2002;236:397-406. doi:10 .1097/00000658-200210000-00001

59. Imamura H, Seyama $Y$, Kokudo N, et al. One thousand fifty-six hepatectomies without mortality in 8 years. Arch Surg 2003; 138:1198- 206. doi:10.1001 Larchsurg.138.11.1198

60. Sun HC, Qin LX, Lu L, et al. Randomized clinical trial of the effects of abdominal drainage after elective hepatectomy using the crushing clamp method. Br J Surg 2006;93:422-66. doi:10.1002/ bjs. 5260

61. Lesurtel M, Selzner M, Petrowsky H, McCormack L, Clavien PA. How should transection of the liver be performed? A prospective randomized study in 100 consecutive patients: comparing four different transection strategies. Ann Surg 2005;242:81422. doi:10.1097/01.sla.0000189121.35617.d7

62. Mullin EJ, Metcalfe MS, Maddern GJ. How much liver resection is too much? Am J Surg 2005; 190: 87-97. doi:10.1016/j.amjsurg.2005.01.043

63. Asiyanbola B, Chang D, Gleisner AL, et al. Operative mortality after hepatic resection: are literature-based rates broadly applicable? J Gastrointest Surg 2008;12:842-51. doi:10.1007/s11605-0080494-y

64. Dimick J B, Cowan JA Jr, Knol JA, Upchurch GR Jr. Hepatic resection in the United States, indications, outcomes, and hospital procedural volumes from a nationally representative database. Arch Surg 2003; 138:185- 91. doi:10.1001/archsurg. 138. $\underline{2.185}$

65. Almersjö O, Bengmark S, Hafström L. Liver resection for cancer. Acta Chir Scand 1976; 142:139- 44.

66. Houssin D, Franco D, Berthelot P, Bismuth H. Heterotopic liver transplantation in end-stage HBsAg-positive cirrhosis. Lancet 1980;1:990-3. doi:10.1016/S0140-6736(80)91435-X

67. Bismuth H, Houssin D. Reduced-sized orthotopic liver graft in hepatic transplantation in children. Surgery 1984; 95:367- 70.

68. Brölsch CE, Stevens LH, Whitington PF. The use of reduced-size liver transplants in children, including split livers and living related liver transplants. Eur J Pediatr Surg 1991;1:166- 71. doi: 10. 1055/s-2008-1042480

69. Azoulay S, Samuel D, Castaing D, et al. Domino liver transplants for metabolic disorders: expe- 
rience with familial amyloidotic polyneuropathy. J Am Coll Surg 1999;189:584-93. doi:10.1016/ S107 2-7515(99)00208-2

70. Figueras J, Parés D, Munar-Ques M, et al. Experience with domino or sequential liver transplantation in patients with familial amyloidotic polyneuropathy. Transplant Proc 2002;34:307-8. doi:10.1 016/S0041-1345(01)02776-2

71. Bismuth H, Samuel D, Castaing D, et al. Orthotopic liver transplantation in fulminant and subfulminant hepatitis. The Paul Brousse experience. Ann Surg 1995;222:109-19. doi:10.1097/00000658199508000-00002

72. Bismuth H, Morino M, Castaing D, et al. Emergency orthotopic liver transplantation in two patients using one donor liver. Br J Surg 1989;76:722-4. doi:10.1002/ bjs.1800760723

73. Azoulay D, Astarcioglu I, Bismuth H, et al. Splitliver transplantation. The Paul Brousse policy. Ann Surg 1996;224:737-46; discussion 746-8. doi:10. 1097/00000658-199612000-00009

74. Bismuth H, Azoulay D, Samuel D, et al. Auxiliary partial orthotopic liver transplantation for fulminant hepatitis. The Paul Brousse experience. Ann Surg 1996;224:712-24; discussion 724-6. doi:10. 1097/00000658-199612000-00007

75. Adam R, Avisar E, Ariche A, et al. Five-year survival following hepatic resection after neoadjuvant therapy for nonresectable colorectal. Ann Surg Oncol 2001;8:347-53. doi:10.1007/s10434-0010347-3

76. Bismuth E, Adam R, Lévi F, et al. Resection of nonresectable liver metastases from colorectal cancer after neoadjuvant chemotherapy. Ann Surg 1996;224:509-20. doi:10.1097/00000658-19961 0000-00009

77. Adam R, Delvart V, Pascal G, et al. Rescue surgery for unresectable colorectal liver metastases downstaged by chemotherapy: a model to predict long term survival. Ann Surg 2004;240:644-57; discussion 657-8.

78. Folprecht G, Gruenberger T, Bechstein WO, et al. Tumour response and secondary resectability of colorectal liver metastases following neoadjuvant chemotherapy with cetuximab: the CELIM randomised phase 2 trial. Lancet Oncol 2010;11:3847. doi:10.1016/S1470-2045(09)70330-4

79. Min BS, Kim NK, Ahn JB, et al. Cetuximab in combination with 5-fluorouracil, leucovorin and irinotecan as a neoadjuvant chemotherapy in pa- tients with initially unresectable colorectal liver metastases. Onkologie 2007;30:637-43. doi:10.11 $\underline{59 / 000109957}$

80. Pozzo C, Barone C, Kemeny NE. Advances in neoadjuvant therapy for colorectal cancer with liver metastases. Cancer Treat Rev 2008;34:293301. doi:10.1016/j.ctrv.2008.01.004

81. Kawasaki S, Makuuchi M, Kakazu T, et al. Resection for multiple metastatic liver tumors after portal embolization. Surgery 1994;115:674- 7.

82. Madoff D, Abdalla E, Vauthey J . Portal vein embolization in preparation for major hepatic resection: evolution of a new standard of care. J Vasc Interv Radiol 2005;16:779-90.

83. Elias D, Santoro R, Ouellet J, Osmak L, de Baere $\mathrm{T}$, Roche A. Simultaneous percutaneous right portal vein embolization and left liver tumor radiofrequency ablation prior to a major right hepatic resection for bilateral colorectal metastases. Hepatogastroenterology 2004;51:1788-91.

84. Hemming A, Reed A, Howard R, et al. Preoperative portal vein embolization for extended hepatectomy. Ann Surg 2003;237:686-91. doi:10.109 7/00000658-200305000-00011

85. Elias D, Ouellet J, De Baere T, Lasser P, Roche A. Preoperative selective portal vein embolization before hepatectomy for liver metastases: long-term results and impact on survival. Surgery 2002;131: 294-9. doi:10.1067/msy.2002.120234

86. Azoulay D, Castaing D, Smail A, et al. Resection of nonresectable liver metastases from colorectal cancer after percutaneous portal vein embolization. Ann Surg 2000;231:480-6. doi:10.1097/000 00658-200004000-00005

87. Shimada $\mathrm{H}$, Tanaka $\mathrm{K}$, Masui $\mathrm{H}$, et al. Results of surgical treatment for multiple ( $>\mathrm{or}=5$ nodules) bi-lobar hepatic metastases from colorectal cancer. Langenbecks Arch Surg 2004;389:114-21. doi:10.1 007/s00423-003-0447-6

88. Akasu T, Moriya Y, Takayama T. A pilot study of multimodality therapy for initially unresectable liver metastases from colorectal carcinoma: hepatic resection after hepatic arterial infusion chemotherapy and portal embolization. J pn J Clin Oncol 1997;27:331- 5. doi:10.1093/jjco/27.5.331

89. Broering D, Hillert C, Krupski G, et al. Portal vein embolization vs. portal vein ligation for induction of hypertrophy of the future liver remnant. J Gastrointest Surg 2002;6:905-13. doi:10.1016/S1 091-255X(02)00122-1 
90. Takayama T, Makuuchi M. Preoperative portal vein embolization: is it useful? J Hepatobiliary Pancreat Surg 2004;11:17-20. doi:10.1007/s005 34-002-0800-0

91. Abdalla EK, Barnett CC, Doherty D, Curley SA, Vauthey J N. Extended hepatectomy in patients with hepatobiliary malignancies with and without preoperative portal vein embolization. Arch Surg 2002;137:675- 80. doi:10.1001/archsurg. 137.6675

92. Wakabayashi H, Ishimura K, Okano K, et al. Application of preoperative portal vein embolization before major hepatic resection in patients with normal or abnormal parenchyma. Surgery 2002; 131:26- 33. doi:10.1067/msy.2002.118259

93. Adam R, Lucidi V, Bismuth H. Hepatic colorectal metastases: methods of improving resectability. Surg Clin North Am 2004;84:659- 71. doi:10.1016/ j.suc.2003.12.005

94. Goere D, Farges O, Leporrier J, Sauvanet A, Vilgrain V, Belghiti J. Chemotherapy does not impair hypertrophy of the left liver after right portal vein obstruction. J Gastrointest Surg 2006;10:365- 70. doi:10.1016/j.gassur.2005.09.001

95. Beal I, Anthony S, Papadopoulou A, et al. Portal vein embolization prior to hepatic resection for $\mathrm{co}^{-}$ lorectal liver metastases and the effects of periprocedure chemotherapy. Br J Radiol 2006; 79:473- 8. doi: $10.1259 / \mathrm{bjr} / 29855825$

96. J aeck D, Bachellier P, Nakano H, et al. One or twostage hepatectomy combined with portal vein embolization for initially nonresectable colorectal liver metastases. Am J Surg 2003;185:221-9. doi:10.1016/S0002-9610(02)01373-9

97. Adam R, Laurent A, Azoulay D, Castaing D, Bismuth $\mathrm{H}$. Two stage hepatectomy: a planned strategy to treat unresectable liver tumors. Ann Surg 2000;232:777-85. doi:10.1097/00000658-2000 $\underline{12000-00006}$

98. Jaeck D, Oussoultzoglou E, Rosso E, Greget M, Weber J C, Bachellier P. A two-stage hepatectomy procedure combined with portal vein embolization to achieve curative resection for initially unresect- able multiple and bilobar colorectal liver metastases. Ann Surg 2004;240:1037- 51. doi:10.1097/0 1.sla.0000145965.86383.89

99. Nguyen KT, Laurent A, Dagher I, et al. Minimally invasive liver resection for metastatic colorectal cancer: a multi-institutional, international report of safety, feasibility, and early outcomes. Ann Surg 2009;250:842- 8. doi:10.1097/SLA.0b013e3181bc $\underline{789 \mathrm{c}}$

100. Nguyen KT, Gamblin TC, Geller DA. World review of laparoscopic liver resection - 2,804 patients. Ann Surg 2009;250:831- 41. doi:10.1097/SLA.0b0 $13 \mathrm{e} 3181 \mathrm{~b} 0 \mathrm{c} 4 \mathrm{df}$

101. Cherqui D, Husson E, Hammoud R, et al. Laparoscopic liver resections: a feasibility study in 30 patients. Ann Surg 2000;232:753- 762. doi:10.1097 /00000658-200012000-00004

102. Cherqui D. Laparoscopic liver resection. Br J Surg 2003;90:644- 6. doi:10.1002/bjs.4197

103. Vibert E, Perniceni T, Levard H, Denet C, Shahri NK, Gayet B. Laparoscopic liver resection. Br J Surg 2006;93:67- 72. doi:10.1002/bjs.5150

104. Gayet B, Cavaliere D, Vibert E, et al. Totally laparoscopic right hepatectomy. Am J Surg 2007; 194: 685- 9. doi:10.1016/j.amjsurg.2006.11.044

105. Gumbs AA, Gayet B, Gagner M. Laparoscopic liver resection: when to use the laparoscopic stapler device. HPB (Oxford) 2008;10:296- 303.

106. Bryant R, Laurent A, Tayar C, Cherqui D. Laparoscopic liver resection-understanding its role in current practice: the Henri Mondor Hospital experience. Ann Surg 2009;250:103-11. doi:10.1097/ SLA.0b013e3181ad6660

107. Soubrane O, Cherqui D, Scatton O, et al. Laparoscopic left lateral sectionectomy in living donors: safety and reproducibility of the technique in a single center. Ann Surg 2006;244:815-20. doi:10. 1097/01.sla.0000218059.31231.b6

108. Idrees K, Bartlett DL. Robotic liver surgery. Surg Clin North Am 2010;90:761-74. doi:10.1016/j. suc.2010.04.020 